Proc. Estonian Acad. Sci. Geol., 2003, 52, 1, 3-27

\title{
Correlation of lower-middle Llandovery sections in central and southern Estonia and sedimentation cycles of lime muds
}

\author{
Heldur Nestor, Rein Einasto, Peep Männik, and Viiu Nestor \\ Institute of Geology, Tallinn Technical University, Estonia pst. 7, 10143 Tallinn, Estonia; \\ hnestor@gi.ee, einasto@gi.ee,mannik@gi.ee,vnestor@gi.ee \\ Received 25 March 2002, in revised form 28 June 2002
}

\begin{abstract}
Stratigraphical units of the Juuru and Raikküla regional stages (lower to middle Llandovery) are described and correlated in the Põltsamaa, Heimtali, and Ikla drill cores. A new unit, the Heinaste Member, is established at the base of the Saarde Formation. The Distomodus kentuckyensis, Aspelundia expansa, and A. fluegeli conodont biozones, as well as the Ancyrochitina laevaensis, Belonechitina postrobusta, Euconochitina electa, Ancyrochitina convexa, Conochitina alargada, and C. malleus chitinozoan biozones are recognized, the last two zones in both groups for the first time in Estonian sections. Biostratigraphical correlation by means of chitinozoans and conodonts proves synchroneity of extensive strata of micritic limestones recurring three times in the sequence of the Raikküla Stage. The pure, micritic limestones, almost barren of benthic shelly fossils, alternate with more argillaceous, nodular, biomicritic limestones (skeletal packstones and wackestones) in the Nurmekund Formation, and with marlstones or argillaceous limestones in the Saarde Formation. Alternation of micritic deposits, very poor in benthic fauna, with argillaceous, biomicritic deposits rich in shelly fauna, suggests that such cyclicity was not directly controlled by changes in water depth, but more likely by cyclic changes in certain biogeochemical conditions. Alternation of arid and humid climate states supposedly induced lime mud accumulation cycles: during humid periods terrigenous input and freshwater runoff from the adjacent continent produced more argillaceous sediments, whereas during the arid periods terrigenous input decreased but salinity increased, causing accumulation of pure lime muds. Cyclic accumulation of lime muds in lowlatitude shallow seas was characteristic of the supposed latest Ordovician-earliest Silurian icehouse period.
\end{abstract}

Key words: Estonia, Llandovery, conodonts, chitinozoans, biostratigraphy, correlation, sedimentation cycles.

\section{INTRODUCTION}

Two confacies belts, with different sets of lithostratigraphical units, have been distinguished within the Estonian part of the Baltic Silurian Basin (Kaljo 1977): 
the comparatively shallow-water confacies in middle Estonia and the deeperwater confacies in southern Estonia-northern Latvia. The boundary between these belts is one of the most significant facies boundaries, separating prevailingly carbonate rocks of the shelf area from the more argillaceous rocks of the deeper basin (e.g. H. Nestor \& Einasto 1977, 1997). During the Silurian, the boundary between these confacies belts gradually shifted southwards due to the progradation of the carbonate shelf.

Lateral facies transition from central to southern Estonian sections in the lower Llandovery Juuru Stage is rather well studied and described (H. Nestor \& Kala 1968). However, a similar transition in the middle Llandovery Raikküla Stage is still rather poorly documented due to an extensive stratigraphical gap in the upper part of the stage in western Estonia and scarcity of deep borings in southeastern Estonia. In order to give the time-rock correlation of the lowermost Silurian strata in central and southern Estonia and determine criteria for lateral delimitation of lithostratigraphical units, three drill cores (Põltsamaa, Heimtali, and Ikla) were studied (Fig. 1). The Põltsamaa drill core from central Estonia, which well characterizes the Middle Estonian Confacies Belt, has been selected as the type section of the Nurmekund Formation of the Raikküla Stage and all its subdivisions (H. Nestor 1993, 1997). The Ikla section at the Estonian-Latvian frontier is the stratotype of the Saarde Formation (Aaloe et al. 1976) and most of its subunits (H. Nestor 1993, 1997). The Heimtali drill section near Viljandi has an intermediate position and enables the tracing of lateral transition from central to southern Estonian sections.

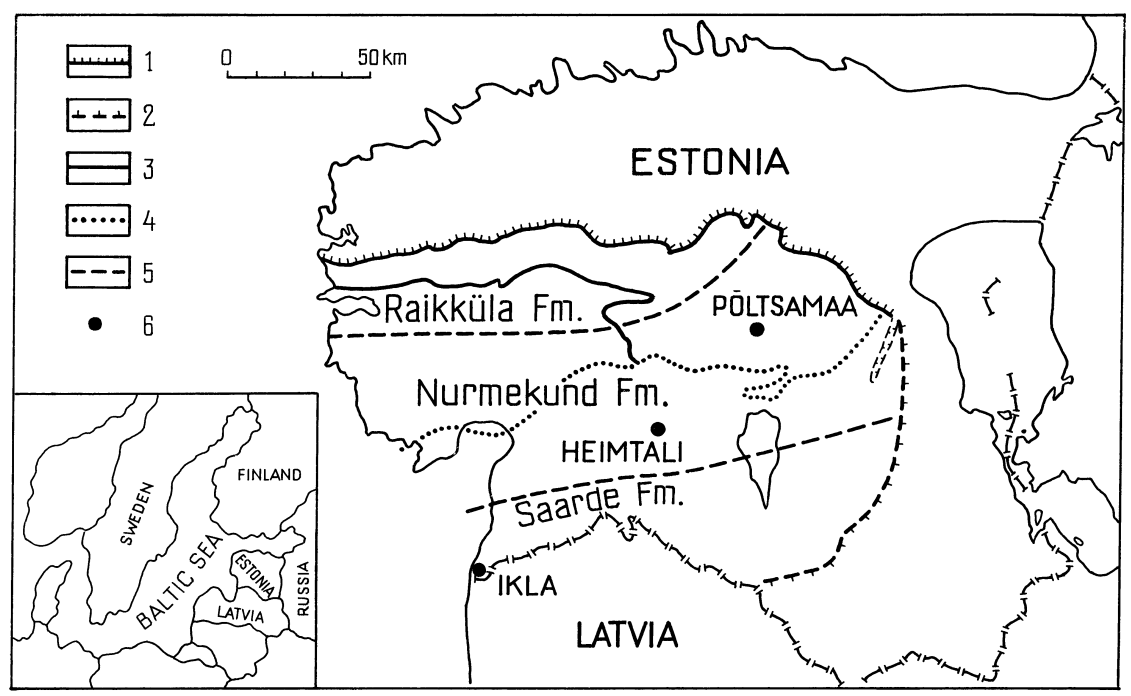

Fig. 1. Location map, showing the present distribution of the formations of the Raikküla Stage in Estonia. 1, outline of the outcrop area; 2, outline of the subsurface distribution of the stage; 3, limit of the overlying Adavere Stage; 4, limit of the Devonian cover; 5, boundary between the distribution areas of formations; 6 , borehole. 
In Estonia, the uppermost Ordovician and the lowermost Silurian are represented by cyclically alternating strata of pure micritic limestones and more argillaceous bioclastic limestones or marlstones (H. Nestor \& Einasto 1997). The aim of the present paper is to give a detailed description of such specific cyclicity and its trends in the Raikküla Stage as well as to detect its possible reasons.

H. Nestor and R. Einasto are responsible for litho- and cyclostratigraphical analyses of the sections. P. Männik studied the distribution of conodonts and V. Nestor that of chitinozoans.

\section{STRATIGRAPHICAL SETTING}

In Estonia, the lowermost Silurian is represented by the Juuru and Raikküla regional stages, which together roughly correspond to the Rhuddanian and Aeronian global stages (Fig. 2). In the Middle Estonian Confacies Belt the Juuru Stage comprises the Varbola Formation (below) and the Tamsalu Formation (above) (e.g. H. Nestor 1997). The latter consists of the Tammiku and Karinu members. In southern Estonia, the whole range of the Juuru Stage is represented by the Õhne Formation. In the transition area, the shifting upwards Varbola Formation laterally replaces the Tamsalu Formation. The Raikküla Stage consists of the Raikküla, Nurmekund, and Saarde formations laterally replacing one another

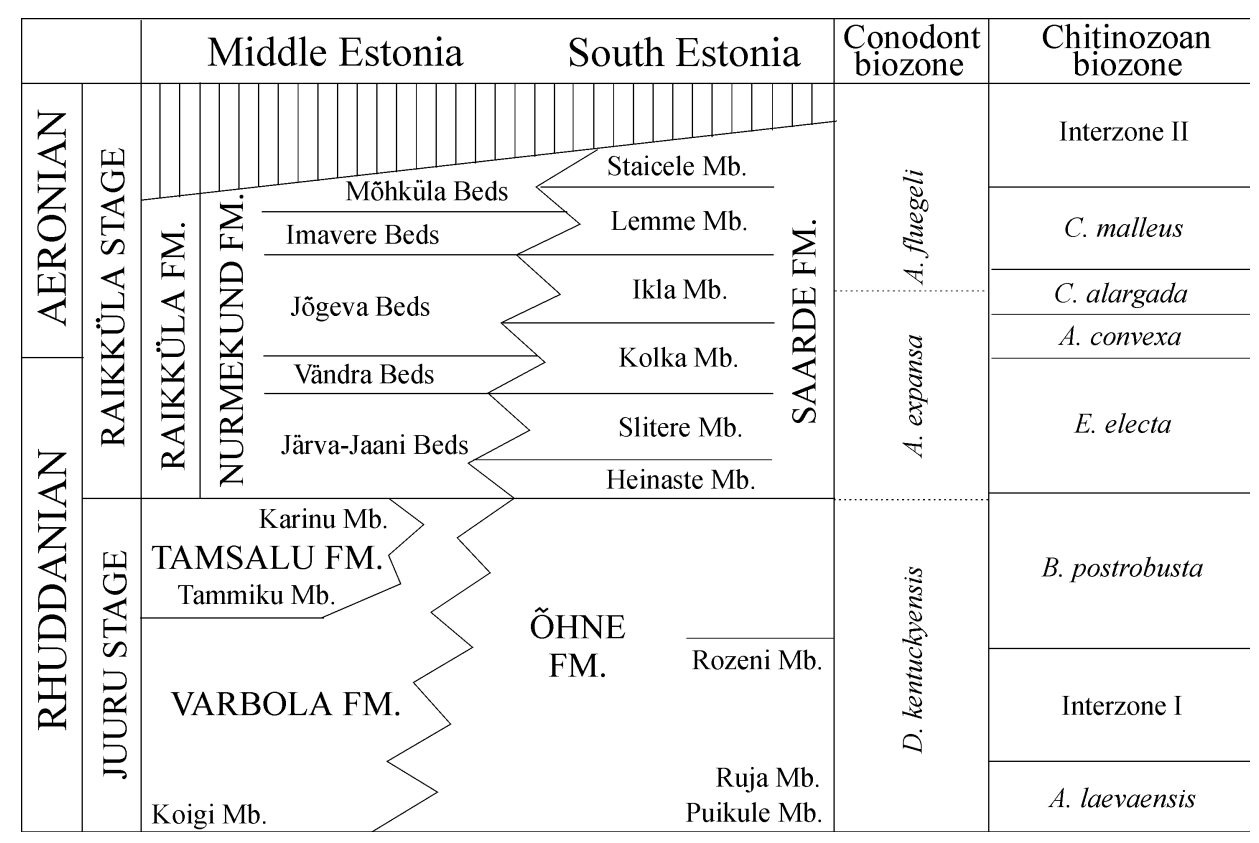

Fig. 2. Correlation of lithostratigraphical units and biozones of the Juuru and Raikküla stages in Estonia. 
(Figs. 1 and 2). The first two formations spread in middle Estonia, the last one in southern Estonia. The Nurmekund Formation is subdivided into more heterogeneous, cyclostratigraphical units - the Järva-Jaani, Vändra, Jõgeva, Imavere, and Mõhküla beds, whereas the Saarde Formation consists of more homogeneous, lithostratigraphical units - the Heinaste (new unit), Slitere, Kolka, Ikla, Lemme, and Staicele members. Southwards, the Saarde Formation is replaced by the succeeding Remte (marlstones) and Dobele (shaly graptolitic claystones) formations.

To correlate lithostratigraphical units of the Middle and South Estonian Confacies Belts, the distribution of microfossils in the Põltsamaa, Heimtali, and Ikla cores was studied and range charts of conodonts and chitinozoans were composed (Figs. 3-5).

\section{DISTRIBUTION OF CONODONTS}

Conodonts are poorly represented in the studied sections as well as in general in the Juuru and Raikküla stages in Estonia (e.g. Männik 1992). The size of our samples was limited (on average less than $1 \mathrm{~kg}$ ), and thus the analysis showed sporadic distribution for most of the taxa. The conodont faunas are dominated by long-ranging simple-cone taxa, which are still too poorly studied to be used effectively in biostratigraphy. However, it is evident that the majority of the taxa identified in open nomenclature in fact include more than one species, e.g. in the Heimtali core, almost all samples with Walliserodus spp. contain at least two different taxa, one of them very similar to $W$. curvatus. To identify properly the different species of Walliserodus (and also those in other similar "groups"), studies of larger collections are needed. Summarizing all data available from the Juuru and Raikküla stages in the northern Baltic, two main ecological associations of conodonts can be recognized in both units.

\section{Juuru Stage}

The relatively poor conodont association of this stage is dominated by Panderodus ex gr. equicostatus (Rhodes). Ramiforms, represented by the genera Distomodus, Oulodus?, and Ozarkodina, are very rare. Only in some samples $O z$. ex gr. oldhamensis (Rexroad) and Distomodus cf. kentuckyensis Branson \& Mehl were identified (Fig. 4). Conodonts are very rare in the Varbola Formation and were absent in most samples from the Põltsamaa core (Fig. 3). Their frequency increases towards the offshore part of the basin, up to several tens (in the Heimtali core, Fig. 4) or even more than a hundred specimens per kilogram (in the Ohesaare core - Männik, unpublished data) in the Õhne Formation. The main difference between the associations from the Varbola and Õhne formations is the occurrence of Dapsilodus in the latter unit. Further offshore, in the Remte Formation (Aizpute core - Loydell et al. in press), Dapsilodus becomes one of the dominant taxa. 


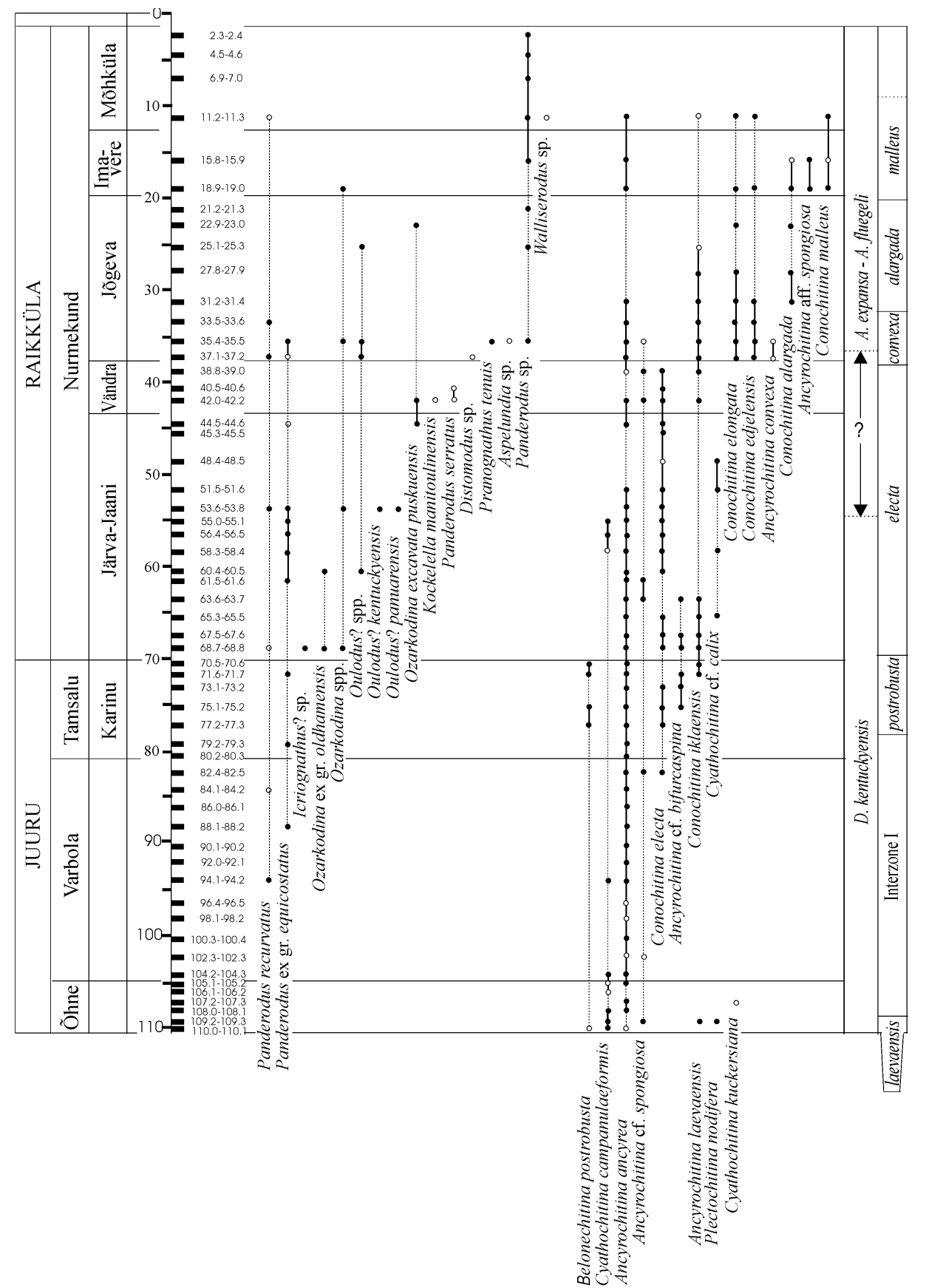

Fig. 3. Range chart of conodonts and chitinozoans in the Põltsamaa core. Columns from left to right show: regional stage; formation; member or beds; depth in metres; number of sample or its interval; distribution of conodonts and chitinozoans (filled circle - reliable identification, empty circle problematic identification); conodont zone; chitinozoan zone. 


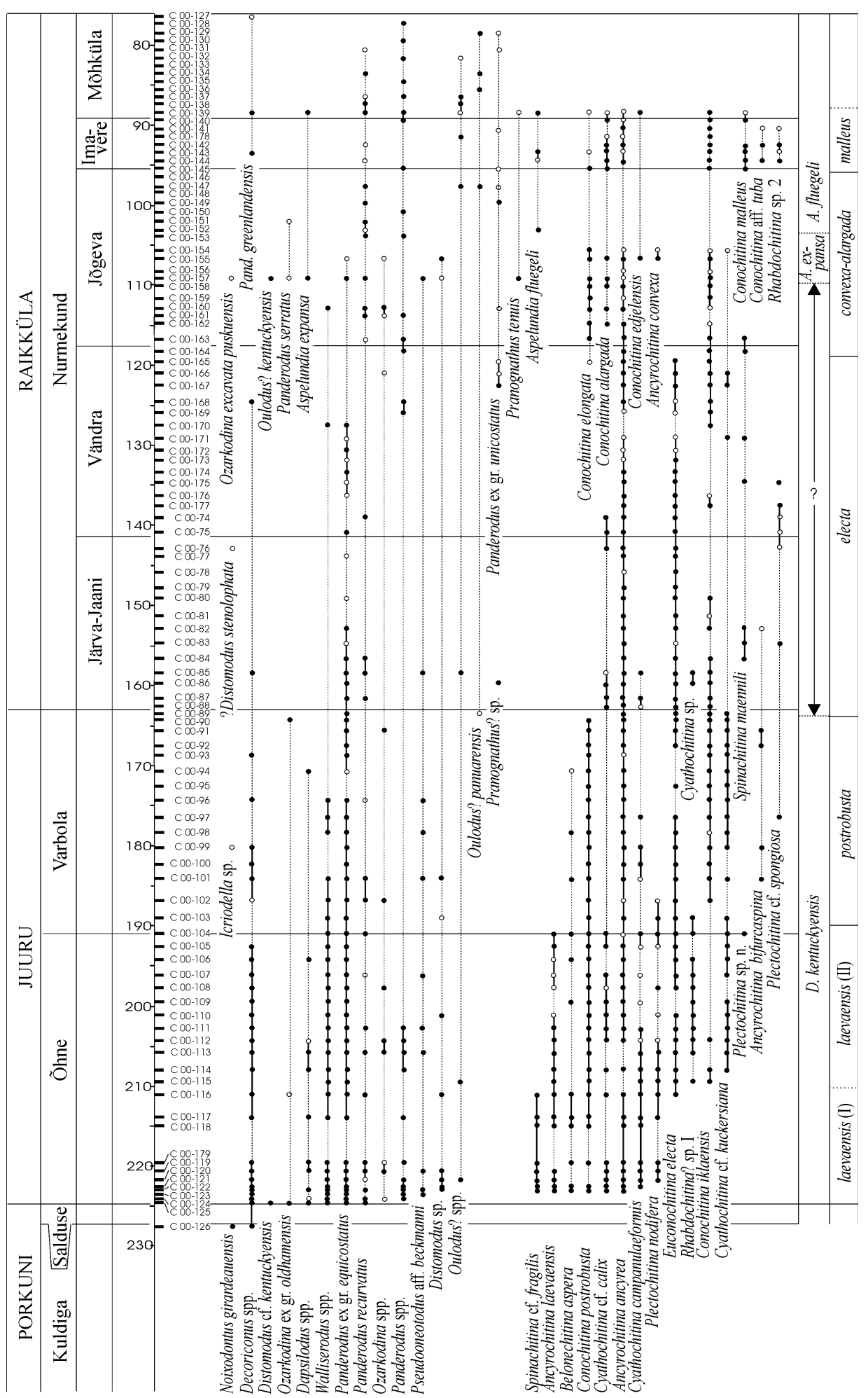


Innovation of the conodont fauna took place in late Juuru time, and several new taxa, such as Ozarkodina excavata puskuensis Männik, Oulodus? panuarensis Bischoff, Aspelundia expansa Armstrong, Kockelella manitoulinensis Pollock, Rexroad \& Nicoll, appeared (Männik 1992, 1994, unpublished data; Loydell et al. in press). However, this event is very poorly represented in the three sections under consideration. Only in the Heimtali core a single Sc element of Oulodus? panuarensis was found just below the contact between the Varbola and Nurmekund formations (sample C 00-89, 163.50-163.60 m; Fig. 4).

\section{Raikküla Stage}

Two distinct ecological associations of conodonts, one in the Raikküla and the other in the Saarde Formation, characterize the Raikküla Stage. The relatively diverse association (although the frequency of specimens is usually less than 10 specimens per kilogram) of the Raikküla Formation (Fig. 2) is dominated by Ozarkodina excavata puskuensis. Common taxa are Panderodus ex gr. unicostatus (Branson \& Mehl), and P. ex gr. greenlandensis Armstrong (Männik 1992, 1994) and several other ramiform conodonts (Distomodus, Kockelella, Oulodus?). But, as a rule, Panderodus ex gr. equicostatus is missing in these faunas (Männik 1994).

No specimens of Panderodus ex gr. unicostatus and $P$. ex gr. greenlandensis were found in the Saarde Formation. Instead, most common in these faunas, dominated by various simple-cone taxa, is $P$. ex gr. equicostatus. As in the Juuru Stage (see above), the genus Dapsilodus becomes more frequent further offshore also in the Raikküla Stage and is one of the dominant taxa in the Dobele Formation (Loydell et al. in press). The general frequency of specimens in the sediments also increases towards the offshore. Ramiforms are rare and occur sporadically in the Saarde Formation. The conodont assemblage of the Nurmekund Formation seems to be transitional between those of the Raikküla and Saarde formations. It still contains rare specimens of Ozarkodina excavata puskuensis but Panderodus ex gr. unicostatus and $P$. ex gr. greenlandensis are replaced by $P$. ex gr. equicostatus.

Aspelundia and Oulodus? panuarensis have been found in all associations (Figs. 3-5). O.? panuarensis is more common in the Raikküla and Nurmekund formations and becomes rarer further offshore (in the Saarde, uppermost Remte, and Dobele formations). Aspelundia, on the contrary, is more frequent in the offshore environments (see also Armstrong 1990) but occurs also in the Raikküla Formation.

Fig. 4. Range chart of conodonts and chitinozoans in the Heimtali core. For explanations refer to Fig. 3. 


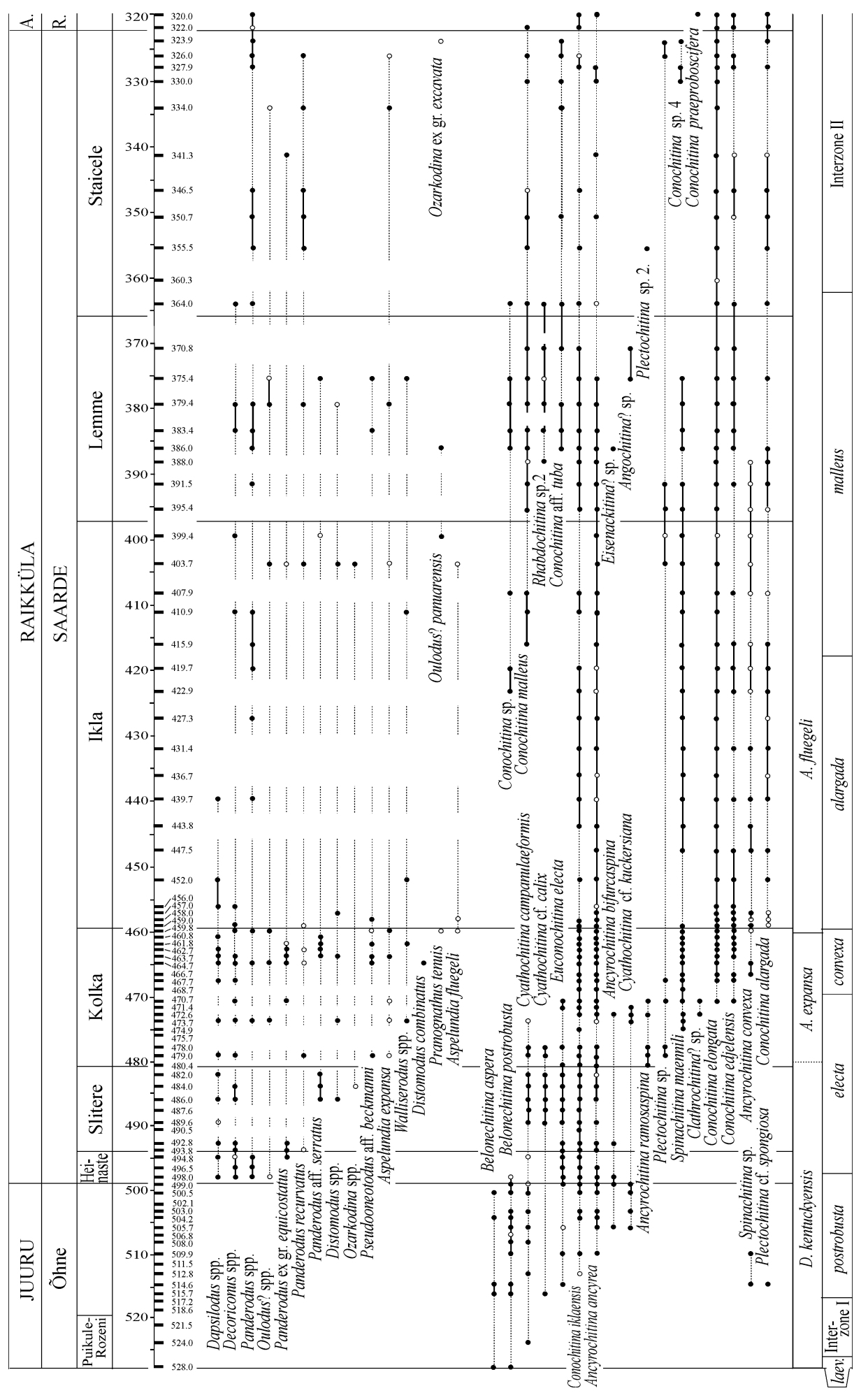




\section{Zonation}

Several possible versions have been proposed for the Rhuddanian-Aeronian conodont zonation, where the evolutionary lineages of two genera, Distomodus and Aspelundia, seem to possess the highest potential (Bischoff 1986; Armstrong 1990; Männik 2001). As poor preservation of the rare specimens does not allow precise identification of the Distomodus species, the conodont biostratigraphy in the studied sections is based on the Aspelundia lineage. The strata below the first appearance of Aspelundia were assigned to the Distomodus kentuckyensis Biozone although the zonal species could not be exactly identified.

Two species of the Aspelundia lineage, A. expansa Armstrong and its descendant A. fluegeli (Walliser), have been described (Armstrong 1990). The oldest well dated A. expansa comes from the upper part of the cyphus graptolite Biozone in the Aizpute core (Loydell et al. in press) which corresponds to the lower part of the Raikküla Stage in the East Baltic (H. Nestor 1997). A. fluegeli appears in the uppermost leptotheca graptolite Biozone (Loydell et al. in press) (=argenteus Biozone in Armstrong 1990). A. fluegeli and A. expansa occur together up to the turriculatus graptolite Biozone (Loydell et al. in press).

The co-occurrence of conodonts, graptolites, and chitinozoans in the Aizpute core allowed detailed correlation of biozones of these three groups (Loydell et al. in press). The A. expansa Biozone correlates with the upper cyphus-upper leptotheca graptolite biozones, and with the Euconochitina electa, Ancyrochitina convexa, and the lower part of the Conochitina alargada chitinozoan biozones. Generally, the upper boundary of the A. expansa Biozone is marked by the appearance of Distomodus staurognathoides, not found in the studied sections. Therefore, the D. staurognathoides Biozone is not indicated in Figs. 3-5 although the strata above the Conochitina alargada Biozone probably belong to this unit (Lloydell et al. in press).

In the Ikla core (Fig. 5), the lowermost record of A. expansa comes from the sample at $479.0 \mathrm{~m}$ in the middle part of the Euconochitina electa chitinozoan Biozone. Aspelundia fluegeli was identified from the sample at $459.8 \mathrm{~m}$, from the topmost Ancyrochitina convexa Biozone. In the Heimtali core (Fig. 4), A. expansa appeared in sample C 00-157, 109.10-109.25 $\mathrm{m}$ and A. fluegeli in sample C 00-152, 103.15-103.25 m (both from the unseparable A. convexaC. alargada interval of chitinozoans). In the Põltsamaa core (Fig. 3), only unidentifiable fragments of Aspelundia were found from a single sample (35.4$35.5 \mathrm{~m}$ ) corresponding to the lower part of the A. convexa Biozone.

As compared with the chitinozoan succession, the appearance of the representatives of the Aspelundia lineage in the three studied sections seems to be diachronous. Obviously they came in earlier in offshore settings. However, most

Fig. 5. Range chart of conodonts and chitinozoans in the Ikla core. For explanations refer to Fig. 3. A - Adavere Stage; R - Rumba Formation; laev. - laevaensis. Barren intervals in the distribution of conodonts indicate that conodonts from these samples were not studied. 
probably, the diachronous appearance of Aspelundia species in the Ikla, Heimtali, and Põltsamaa cores is caused by the limited size of our samples (on average less than $1 \mathrm{~kg}$ ). As a result, commonly less than 10 conodont specimens per sample were found from the Heimtali and Põltsamaa cores, which is inadequate for tracing continuous ranges of the species. Rare occurrence and poor preservation of Aspelundia specimens in the studied sections do not allow precise definition of the lower boundaries of the A. expansa and A.fluegeli biozones. For indirect determination of the base of the A. expansa Biozone data on the distribution of Oulodus? panuarensis can be used. In the Aizpute core, the first $O . ?$ panuarensis is found just above the lowermost sample with A. expansa (Loydell et al. in press). Both taxa appear in the cyphus graptolite Biozone: A. expansa in the uppermost Belonechitina postrobusta chitinozoan Biozone and O.? panuarensis in the lowermost Euconochitina electa chitinozoan Biozone. The level of the appearance of A. expansa in the Põltsamaa, Heimtali, and Ikla cores is evidently diachronous and the actual lower boundary of the A. expansa Biozone may lie just below the appearance of O.? panuarensis in the Heimtali and Põltsamaa cores. Such an alternative position of the biozone boundary is shown in the range charts (Figs. 3-5). The strata below the A. expansa Biozone are tentatively assigned to the Distomodus kentuckyensis Biozone.

\section{DISTRIBUTION AND ZONATION OF CHITINOZOANS}

\section{Juuru Stage}

The greatest differences in the occurrence, diversity, and abundance of chitinozoans are recorded in the Juuru Stage. The lowermost part of the stage is represented by the Õhne Formation in all three cores. Chitinozoans are rare in the Põltsamaa core (Fig. 3), but rather abundant in the Heimtali (Fig. 4) and Ikla (Fig. 5) cores. The middle part of the stage is characterized by a diverse and rich assemblage of chitinozoans only in the Heimtali core (Õhne Formation), scarce specimens occur in the Põltsamaa core (Varbola Formation) and barren intervals in the Ikla core (Õhne Formation). The upper part of the Juuru Stage includes a rather diverse assemblage of chitinozoans in the Põltsamaa core (Tamsalu Formation) as well as in Heimtali (Varbola Formation) and Ikla (Õhne Formation).

Traditionally, the Ancyrochitina laevaensis Biozone is regarded as the lowermost Silurian chitinozoan biozone in the East Baltic sections (V. Nestor 1994). It includes a typical zonal assemblage in the Põltsamaa core (107.5-110.2 m, Fig. 3), but is impoverished in Ikla $(525.6-528.0 \mathrm{~m})$, where the index species was not established (Fig. 5). In the Heimtali core, this biozone (190.0-223.8 m) includes a diverse and abundant assemblage (Fig. 4) and, besides, has a maximum thickness, which is more than five times the thickness of the biozone in all other, previously studied sections (V. Nestor 1994). In Heimtali this biozone can be divided into two parts. The lower part (I in Fig. 4) includes Spinachitina cf. 
fragilis (Nestor) (long form; 210.0-223.8 m). The upper part (II) (210.0-190.0 m) contains Rhabdochitina sp. 1, Euconochitina electa (Nestor), and Conochitina iklaensis Nestor, which have never been found in the Ancyrochitina laevaensis Biozone before (see V. Nestor 1994). Thus, it seems that in the Heimtali core the upper part (II) of the A. laevaensis Biozone corresponds to Interzone I (V. Nestor 1994) in other sections: an interval, devoid of specific taxa in the Põltsamaa core or almost barren of chitinozoans in the Ikla core.

The Belonechitina postrobusta Biozone was established in the upper part of the Juuru Stage: in the Tamsalu Formation in the Põltsamaa core (70.0-78.0 m), in the Varbola Formation in the Heimtali core $(163.0-190.0 \mathrm{~m})$, and in the uppermost part of the Õhne Formation in the Ikla core (497.5-516.0 m). In Heimtali, the index species ranges continuously throughout the Juuru Stage. The lower boundary of the biozone can be established only by the disappearance of Ancyrochitina laevaensis Nestor and the upper boundary by the disappearance of Belonechitina postrobusta (Nestor). In the Põltsamaa and Ikla cores, the lower boundary of the biozone is determined by the reappearance of the zonal species above Interzone I.

\section{Raikküla Stage}

The Raikküla Stage, especially its lower part, is characterized by abundant chitinozoans in all three core sections. No remarkable differences could be noticed in taxonomic diversity and assemblage of the Järva-Jaani and Vändra beds in the Põltsamaa and Heimtali cores on one hand, and between the Slitere and Kolka members in the Ikla core on the other hand. In the upper part of the stage, the diversity of chitinozoans is more variable. For example, the uppermost Jõgeva Beds in the Heimtali core are barren of chitinozoans. In the Põltsamaa core, the corresponding beds contain only rare specimens, whereas in Ikla a diverse and abundant assemblage of chitinozoans occurs to the full extent of the coeval Ikla Member. The Imavere Beds in the Põltsamaa and Heimtali cores contain more frequent chitinozoans than the lower-lying beds, while both, specimens and species occur abundantly in the Lemme Member in the Ikla core. The Mõhküla Beds in the Põltsamaa and Heimtali cores are practically barren of chitinozoans, whereas in the Staicele Member in Ikla the abundance and diversity of chitinozoans decreases considerably.

The uppermost Rhuddanian Euconochitina electa Biozone corresponds to the lower part of the Raikküla Stage, i.e. to the Järva-Jaani and Vändra beds in the Põltsamaa (38.0-70.0 m) and Heimtali (118.0-163.0 m) cores. In Ikla, it corresponds to the Heinaste and Slitere members and to the lower part of the Kolka Member (469.0-497.5 m). As mentioned above, the lower boundary of this biozone is defined by the disappearance of Belonechitina postrobusta, but the zonal species itself appears already in the middle or upper part of the Juuru Stage. The continuous range of Euconochitina electa (Nestor) is about $90 \mathrm{~m}$ in the Heimtali core but about $45 \mathrm{~m}$ in Ikla and Põltsamaa. The zonal assemblage is 
more diverse in Ikla, including Conochitina iklaensis, Cyathochitina cf. calix, C. cf. kuckersiana, Ancyrochitina ramosaspina Nestor, and Spinachitina maennili (Nestor); the last species occurs only in the uppermost part of the zone in the Ikla and Heimtali cores. Spinachitina maennili is not recorded in the Põltsamaa core, due to biofacies differences established in the East Baltic area (V. Nestor 1998).

The lowermost Aeronian Ancyrochitina convexa Biozone is rather thin and corresponds to the lowermost part of the Jõgeva Beds in the Põltsamaa core (32.0-38.0 m) and to the upper part of the Kolka Member in the Ikla core (459.4$469.0 \mathrm{~m}$ ). The lower boundary of the biozone is determined by the disappearance of Euconochitina electa and by the appearance of the zonal species. Conochitina elongata Taugourdeau and C. edjelensis Taugourdeau appear approximately at the same level. In Heimtali, Ancyrochitina convexa Nestor and Conochitina edjelensis are found much higher than the disappearance of Euconochitina electa and even higher than the appearance of the index species of the succeeding Conochitina alargada Biozone (Fig. 4). This may be explained by relatively low frequency of Ancyrochitina convexa in many sections. Therefore, the A. convexa and C. alargada biozones are treated together in the Heimtali core (Fig. 4). Besides the species listed above, Conochitina iklaensis occurs numerously in all cores and Spinachitina maennili in the Ikla core.

The assemblage of the Conochitina alargada Biozone is best represented in the Ikla core (418.0-459.4 m), somewhat impoverished in the Põltsamaa core (20.0-32.0 m), and not separable from the Ancyrochitina convexa Biozone in the Heimtali core. The lower boundary of the zone is defined by the first appearance of the index species $C$. alargada Cramer, which was earlier used as a zonal species in a global biozonation for the Silurian (Verniers et al. 1995). In the East Baltic sections, the $C$. alargada Biozone is now separated as an independent unit from the upper part of the former Ancyrochitina convexa Biozone s.l. (V. Nestor 1994). The biozone corresponds to the main part of the Jõgeva Beds (except the lowermost layers) in the Põltsamaa core and to the lower two-thirds of the Ikla Member in the Ikla core. Besides the zonal species, Conochitina iklaensis and C. elongata are the most common species in all three sections, additionally also Spinachitina maennili in the Ikla core.

The Conochitina malleus Biozone corresponds mainly to the Imavere Beds in the Põltsamaa (10.0-20.0 m) and Heimtali $(88.0-96.0 \mathrm{~m})$ cores, as well as to the uppermost part of the Ikla Member and to the Lemme Member in the Ikla core (361.0-418.0 m). Conochitina malleus Van Grootel (nomen nudum) was described in the unpublished Ph.D. thesis (1990) and used first as a biozonal species by Dufka (zone C in Dufka 1992). In the present work, the C. malleus Biozone is used in the Estonian biozonal scheme mostly instead of the former $C$. cf. protracta Biozone (V. Nestor 1994), which was based on dubious identification of a taxon in open nomenclature. The lower boundary of the C. malleus Biozone is defined by the first appearance of the index species. In the Heimtali core, the upper part of the Jõgeva Beds is barren of chitinozoans. This interval probably corresponds to the lower part of the C. malleus Biozone, because in this core C. malleus 
appears at the base of the Imavere Beds together with Rhabdochitina sp. 2, which in the Ikla core occurs only in the upper part of the $C$. malleus Biozone. Besides the zonal species, the $C$. malleus Biozone contains $C$. alargada, C. elongata, and C. iklaensis in all sections and $C$. aff. tuba Eisenack and Rhabdochitina sp. 2 in Ikla and Heimtali. Spinachitina maennili is abundant in the lower part of the biozone in the Ikla core, but disappears in the upper part of the section. Angochitina? sp. was established in the middle-upper part of the Lemme Member in Ikla, but was not found in other cores.

Interzone II, distinguished by V. Nestor (1994), corresponds to the Staicele Member in the Ikla core (322.3-361.0 m) and contains a poor assemblage of chitinozoans including rare representatives of the transitional species Conochitina malleus, C. iklaensis, C. elongata, C. alargada, and C. aff. tuba. Actually, this unit is a continuation of the Conochitina malleus Biozone as nearly all species except Spinachitina maennili and Rhabdochitina sp. 2 range over from the lowerlying strata. The Mõhküla Beds in the Põltsamaa and Heimtali cores are barren of chitinozoans except the lowermost samples of both cores, which contain elements of the $C$. malleus assemblage.

\section{DESCRIPTION AND CORRELATION OF SEQUENCES}

The correlation of the lower-middle Llandovery strata in central and southern Estonia is based on biostratigraphical and cyclostratigraphical analyses.

\section{Juuru Stage}

In the studied area the Juuru Stage consists of the Õhne, Varbola, and Tamsalu formations, laterally and vertically replacing one another and having transitional, diachronous boundaries. The stage represents a shallowing upwards sedimentation cycle of the mesocycle rank (e.g. H. Nestor \& Kala 1968, H. Nestor \& Einasto 1997).

The Õhne Formation is distributed in southern Estonia and consists of marlstones or mudstones with nodules of argillaceous, micritic limestone. Discontinuity surfaces, tempestite interlayers, corals, stromatoporoids, and skeletal detritus (bioclasts) of benthic fossils are almost lacking. In the Ikla core, the Õhne Formation embraces the whole span (499.0-527.3 m) and in the Heimtali core the lower half of the Juuru Stage (191.0-224.6 m). In the Põltsamaa core, only the lowermost $5.4 \mathrm{~m}$ of the stage $(104.8-110.2 \mathrm{~m})$ is included in the Õhne Formation due to the lack of bioclasts (Fig. 6). The Õhne Formation corresponds to the transitional, or IV, facies zone according to the facies model by H. Nestor \& Einasto (1977, 1997). Two chitinozoan biozones, Ancyrochitina laevaensis and Belonechitina postrobusta, are recognized in the Õhne Formation in the Ikla core. These zones are separated by a barren interval called Interzone I (V. Nestor 1994). 


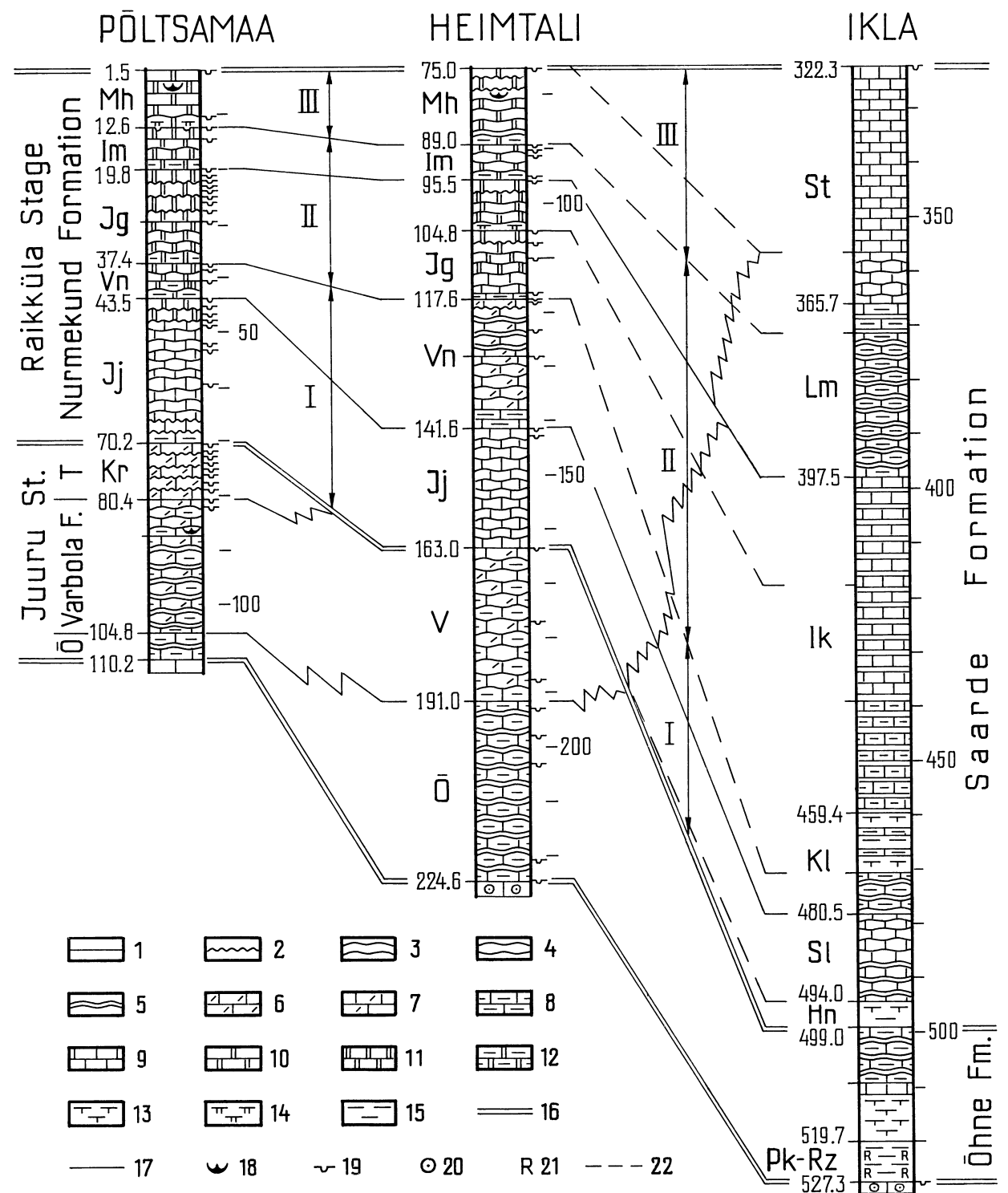

Fig. 6. Lithological logs and correlation of the studied sections. 1, horizontal bedding; 2, rough bedding; 3, wavy bedding; 4, nodular bedding; 5, limestone-marlstone (mudstone) intercalation (about $1: 1$ ); 6, skeletal packstone; 7, skeletal wackestone; 8, argillaceous limestone; 9, micritic limestone; 10, medium- to coarse-crystalline dolostone; 11, fine-crystalline (micritic) dolostone; 12, argillaceous dolostone; 13 , marlstone; 14 , dolomitic marlstone; 15 , mudstone; 16 , stage boundary; 17 , boundary of lithostratigraphical units; 18 , brachiopod coquina; 19, discontinuity surface; 20, oolites; 21, red beds; 22, correlation line. Arabic numerals show depths in metres. Arrows with Roman numerals I-III show spans of mesocycles. Abbreviations of stratigraphical units: Õ - Õhne, V - Varbola, T - Tamsalu formations; Jj - Järva-Jaani, Vn - Vändra, Jg - Jõgeva, Im - Imavere, Mh - Mõhküla beds; Pk-Rz - Puikule + Ruja + Rozeni members; Hn - Heinaste, Sl - Slitere, $\mathrm{Kl}$ - Kolka, Ik - Ikla, Lm - Lemme, St - Staicele, $\mathrm{Kr}$ - Karinu members. 
In the Heimtali core, chitinozoans are quite common at the level of Interzone I and suggest continuation of the A. laevaensis Biozone (designated as laevaensis II in Fig. 4).

The Varbola Formation, which in the Middle Estonian Confacies Belt, including the Põltsamaa core, occurs in the lower half of the Juuru Stage, slides gradually upwards in the sequence due to the progradation of the carbonate shelf and forms the upper part of the Juuru Stage in the Heimtali core (Fig. 6). The intervals of the Varbola Formation in the Põltsamaa (80.4-104.8 m) and Heimtali $(163.0-191.0 \mathrm{~m})$ cores represent a peripheral part of the formation, consisting of variously argillaceous, nodular, biomicritic limestones (prevailingly wackestone) with wavy intercalations of argillaceous marlstone. The clay content is variable in the sequence and displays complicated multistage cyclicity comparable with that of the middle Wenlock Riksu Formation which probably reflects the so-called Milankovitch astronomical cycles (H. Nestor et al. 2001). In the area considered, the Varbola Formation was deposited in the outer part of the open shelf (or IIIb) facies zone below the storm-wave base, because tempestite interlayers and discontinuity surfaces are almost lacking. Rare scattered valves of the brachiopod Borealis borealis in the upper part of the Varbola Formation in the Põltsamaa core (interval 82.0-87.0 m) indicate that in this section the top of the Varbola Formation is contemporaneous with the Tammiku Member of the Tamsalu Formation, which in its type area is represented by the coquina bank of Borealis borealis. In the Põltsamaa core, the Varbola Formation is devoid of decisive chitinozoans and corresponds to chitinozoan Interzone I in the middle of the Juuru Stage (V. Nestor 1994). In the Heimtali core, the Varbola Formation coincides with the Belonechitina postrobusta Biozone (Fig. 4), which specifies the upper part of the Juuru Stage.

The Tamsalu Formation can be recognized only in the Põltsamaa core (70.2$80.4 \mathrm{~m}$ ), where it is represented by the peripheral part of its upper, Karinu Member. It immediately overlies the Varbola Formation (Fig. 6) containing rare Borealis borealis in its topmost part. Thus the Tammiku Member is lithologically indistinguishable in this section. The Karinu Member consists mainly of roughbedded skeletal packstone with tempestite interlayers, pyritized lithoclasts, rounded skeletons of stromatoporoids, and numerous pyritized discontinuity surfaces, indicating deposition in the inner part of the open shelf (IIIa) facies zone, from time to time influenced by storm waves and currents. A comparatively rich assemblage of the Belonechitina postrobusta chitinozoan Biozone occurs in the Karinu Member (Fig. 3).

\section{Raikküla Stage}

The Raikküla Stage is represented by the Nurmekund and Saarde formations in the Middle and South Estonian confacies belts, respectively. The Nurmekund Formation consists of cyclically alternating strata of micritic and bioclastic limestones formed in the open shelf (III) facies zone. In the Saarde Formation, 
the micritic limestones alternate with marlstones or mudstones formed in the transitional (IV) facies zone. Three sedimentary mesocycles have been established in the Nurmekund and Saarde formations (Kaljo \& Vingisaar 1969; H. Nestor \& Einasto 1997), each containing mainly pure micritic calcareous sediments in the lower part (lower submesocycle) and nodular, bioclastic, argillaceous limestones or marlstones in the upper part (upper submesocycle) (Fig. 6). The submesocycles, termed as "beds" in the Nurmekund Formation, begin with a more argillaceous basal layer and show a shallowing upward trend of development.

\section{Mesocycle I}

In central Estonia, the lower submesocycle of Mesocycle I is represented by the Järva-Jaani Beds of the Nurmekund Formation and consists mainly of pure, wavy-bedded to nodular, micritic limestone almost devoid of benthic shelly fossils and bioclasts, but with specific, brown organic detritus of "dendroids" Leveillites and Rhadinograptus at slightly kerogenous, marly bedding planes (Kaljo 1970). A less than $1.0 \mathrm{~m}$ thick layer of more uniform argillaceous limestone or calcareous marlstone, sometimes informally called the Pusku Member, commonly occurs at the base of the Järva-Jaani Beds. In the upper part of the beds, pyritized discontinuity surfaces, grainstone, tempestite interlayers, and very pure, rough-bedded limestones occur in the Põltsamaa core (interval 43.5-48.5 m). This shows a shallowing upwards trend in sedimentation in the open shelf (facies zone III) setting. In the Heimtali core (141.6-163.0 m), only a few discontinuity surfaces occur at the very top of the Järva-Jaani Beds, showing that deposition proceeded almost constantly below the storm-wave base, i.e. in facies zone IIIb.

In southern Estonia, the lower submesocycle of Mesocycle I is represented by the successive Heinaste Member (below) and the Slitere Member (above) of the Saarde Formation.

The Heinaste Member (a new unit, named after ancient Heinaste harbour near Ikla) consists in the stratotype Ikla section (494.0-499.0 m) of dense, slightly dolomitized calcareous marlstone with graptolites Dimorphograptus confertus (Nicholson), Rhaphidograptus toernquisti Elles \& Wood, and Přibylograptus sandersoni (Lapworth) (Kaljo \& Vingisaar 1969), dated as the D. confertus Zone (Kaljo et al. 1984) at the level of the middle Rhuddanian. The interval was previously attributed to the top of the Õhne Formation of the Juuru Stage (Kaljo \& Vingisaar 1969) but was later transferred to the Saarde Formation (e.g. V. Nestor 1994; H. Nestor 1997). By the distribution of chitinozoans and by carbon isotope curves, the member is correlatable with a similar marlstone layer at the base of the Raikküla Stage in western Estonia, informally called the Pusku Member (V. Nestor 1994; Kaljo \& Martma 2000). The latter, however, is more calcareous and contains shelly fossils instead of graptolites. In the studied sections the base of the Heinaste Member correlates with the base of the Järva-Jaani Beds by the disappearance of chitinozoans Belonechitina postrobusta and B. aspera (Figs. 3-5), which define the lower boundary of the Euconochitina electa Biozone and also the beginning of the Raikküla Stage. 
The Slitere Member overlies the Heinaste Member in the Ikla core $(480.5-494.0 \mathrm{~m})$ and is represented by rough-nodular micritic limestone, which corresponds to the upper, main part of the Järva-Jaani Beds (Fig. 2). The upper boundary of the Slitere Member correlates with the top of the Järva-Jaani Beds and is expressed as a sharp lithological boundary of the shallowing-up submesocycle in the middle of the range of the Euconochitina electa Biozone.

The upper submesocycle of Mesocycle $I$ is represented by bioclastic limestones (skeletal pack- and wackestones) of the Vändra Beds in central Estonia and by marlstones of the lower half of the Kolka Member in southern Estonia, respectively.

The Vändra Beds are most representative in the Heimtali core (117.6-141.6 m), consisting there of nodular biomicritic limestones (skeletal packstones or wackestones) with typical shelly fauna of the Stricklandia Community. The beds are lithologically very similar to the Varbola Formation in the Heimtali and Põltsamaa cores, i.e. they were deposited in the outer part of the open shelf (IIIb) facies zone. In the Põltsamaa core, the Vändra Beds $(37.4-43.5 \mathrm{~m}$ ) have a reduced thickness and the rock is heavily dolomitized, so that the primary texture is unrecognizable. The Vändra Beds correspond to the upper part of the Euconochitina electa Biozone (Figs. 3 and 4).

Southwards the biomicritic limestones of the Vändra Beds are replaced by marlstones and nodular, argillaceous limestones which form the lower part of the Kolka Member of the Saarde Formation in the Ikla core (469.7-480.5 m). The unit was formed in the setting of the transitional (IV) facies zone. The lower part of the Kolka Member corresponds to the uppermost Euconochitina electa Biozone (Fig. 5).

\section{Mesocycle II}

The lower submesocycle of Mesocycle II is represented by the Jõgeva Beds of the Nurmekund Formation in central Estonia and by the upper part of the Kolka Member and the Ikla Member of the Saarde Formation in southern Estonia. In the Ikla core, the more argillaceous upper part of the Kolka Member (interval 459.4-469.7 m), represented mainly by uniform marlstone and dated as the Ancyrochitina convexa Biozone (Fig. 5), correlates with the lowermost, argillaceous basal layer of the Jõgeva Beds in the Nurmekund Formation (Figs. 2 and 6). In the Aizpute core, Ancyrochitina convexa has been identified from the Demirastrites triangulatus graptolite Biozone at the base of the Aeronian (Loydell et al. in press). It means that the beginning of the second Raikküla mesocycle, in the middle of the Kolka Member and at the base of the Jõgeva Beds, roughly coincides with the lower boundary of the Aeronian (Figs. 2 and 6). The basal marlstone layer of the Jõgeva Beds and upper part of the Kolka Member are overlain by a second thick deposit of micritic limestones or secondary dolostones.

In the Ikla core (in the interval of 397.5-459.4 m), horizontal-bedded, micritic limestones of the Ikla Member intercalate with microlaminated, shaly, kerogenous mudstones which in the lower part contain numerous graptolites of 
the Demirastrites triangulatus Biozone (Kaljo \& Vingisaar 1969). Upwards the mudstone interlayers become gradually less kerogenous and graptolites much rarer. Such a trend is accompanied by a positive shift in the carbon isotope values reaching a maximum $(+3.7 \%$ ) in the middle-upper part of the Ikla Member (Kaljo $\&$ Martma 2000). The lower two-thirds of the Ikla Member (418.0-459.4 m), rich in graptolites, correspond to the Conochitina alargada chitinozoan Biozone and the upper third (397.5-418.0 $\mathrm{m}$ in Ikla) coincides with the lower part of the Conochitina malleus Biozone (Fig. 5).

Northwards the horizontal-bedded micritic limestones and shaly mudstones of the Ikla Member are replaced by the main part of the Jõgeva Beds of the Nurmekund Formation (Fig. 6), which consists of wavy-bedded to nodular secondary micritic dolostone intercalating with thin interlayers or films of dolomitic marlstone. The marlstone intercalations are mostly light-brown, microlaminated, contain kerogenous material and specific organic detritus of "dendroids" Leveillites and Rhadinograptus. The upper part of the Jõgeva Beds contains tempestite interlayers and pyritized discontinuity surfaces, which are most frequent in the Põltsamaa core and show a shallowing upward trend of development. The lower half of the Jõgeva Beds corresponds to the successive Ancyrochitina convexa and Conochitina alargada chitinozoan biozones, which in the Heimtali core could not be exactly distinguished. The upper part of the Jõgeva Beds is almost devoid of chitinozoans. By its stratigraphical position, this impoverished interval probably corresponds to the lower part of the Conochitina malleus Biozone in the uppermost Ikla Member (397.5-418.0 m in the Ikla core; Fig. 5). This shows that the upper boundaries of the Jõgeva Beds and the Ikla Member are approximately coeval.

The upper submesocycle of Mesocycle II is represented by wavy-bedded to nodular secondary dolostones of the Imavere Beds of the Nurmekund Formation in central Estonia. The primary texture of these rocks is almost unrecognizable, especially in the strongly dolomitized Põltsamaa core $(12.6-19.8 \mathrm{~m})$, where a lithologically very variable interval is capped with a layer of red, microlaminated dolomitic mudstone with probable mud-cracks at the top. Such a succession reveals a sharp, shallowing upwards trend of development through the open shelf (III) to lagoonal (I) facies zones and can be treated as a distinct upper submesocycle of the second Raikküla mesocycle. In the Heimtali core $(89.0-95.5 \mathrm{~m})$, the whole interval consists of nodular, highly porous dolostone with scattered skeletons of corals and stromatoporoids and can be interpreted as secondarily dolomitized biomicritic limestone, formed in the open shelf environment (facies zone III). In the Heimtali core, the Imavere Beds correspond to the upper part of the Conochitina malleus chitinozoan Biozone, as they contain Rhabdochitina sp. 2 and Conochitina aff. tuba lacking in the lower part of the C. malleus Biozone in the Ikla core.

In southern Estonia, the upper submesocycle of Mesocycle II is represented by intercalating nodular, argillaceous limestones and marlstones of the lower part of the Lemme Member of the Saarde Formation (Figs. 2 and 6), occurring in the 
Ikla core in the interval of 365.7-397.5 m. The member contains chitinozoans characteristic of the upper part of the Conochitina malleus Biozone (Fig. 5) and correlates with the Imavere Beds in the Heimtali core by the cooccurrence of the zonal species with Rhabdochitina sp. 2 and Conochitina aff. tuba.

\section{Mesocycle III}

The topmost part of the Lemme Member is more argillaceous, uniform, and horizontally bedded and is therefore regarded as the basal layer of the next Mesocycle III of the Raikküla Stage (Fig. 6). In the Nurmekund Formation, an analogous argillaceous layer is included in the Mõhküla Beds, as its lower boundary is lithologically very sharp, with probable mud cracks in the Põltsamaa core, but the upper contact is quite transitional.

In southern Estonia, the Saarde Formation and Raikküla Stage end with the Staicele Member. In the Ikla core (322.3-365.7 m), the member is represented by micritic limestone with thin intercalations or films of calcareous marlstone at bedding planes. The limestone is partly dolomitized and contains siliceous concretions in the topmost part of the unit (322.3-332.0 m). The upper boundary of the member is marked by a pyritized erosional surface which probably truncates the top of the third mesocycle (H. Nestor \& V. Nestor 2002). The graptolite Petalograptus minor Elles has been recorded from the very base of the unit (Kaljo \& Vingisaar 1969) and the brachiopod Stricklandia lens progressa Williams at a depth of $355.9 \mathrm{~m}$ (Rubel 1977), both referring to an Aeronian age of the Staicele Member. The Staicele Member is overlain by the Rumba Formation, which in Ikla contains Stricklandia laevis (= S. lens ultima in Rubel 1977), a guide fossil of the Telychian in its type area. The impoverished chitinozoan assemblage of the Staicele Member does not contain specific taxa and has been treated as chitinozoan Interzone II (Fig. 5).

In central Estonia, in the Põltsamaa and Heimtali cores, the Staicele Member is replaced by the Mõhküla Beds. The unit is lithologically variable and very heavily dolomitized. It consists mainly of wavy-bedded fine-crystalline dolostone which can be interpreted as a secondarily dolomitized micritic limestone. The upper part of the member $(1.5-8.0 \mathrm{~m}$ in the Põltsamaa core and $75.0-79.5 \mathrm{~m}$ in the Heimtali core) is represented by porous dolostone with frequent interbeds and lenses of silicified coquina of a brachiopod Borealis sp. (identification by M. Rubel). The presence of coquina interbeds indicates that deposition proceeded in the inner part of the open shelf facies zone (IIIa) by H. Nestor \& Einasto (1977). Chitinozoans of the Conochitina malleus Biozone occur at the base of the Mõhküla Beds, but are totally lacking higher. A very strong erosional surface between the Mõhküla Beds and the Devonian in the Heimtali core, and a much lesser thickness of the former unit suggest that the Mõhküla Beds are probably incomplete and correspond only to the lower part of the Staicele Member in the Ikla core (Fig. 6). 


\section{LIME MUD ACCUMULATION CYCLES}

A specific feature of the middle Llandovery Raikküla Stage is cyclic alternation of pure, micritic limestones (lime mudstones) with more argillaceous, bioclastic limestones in the Nurmekund Formation or with marlstones in the Saarde Formation. The alternating strata form three medium-rank sedimentary cycles (Fig. 6) treated as mesocycles (e.g. H. Nestor \& Einasto 1997). The lower parts of these mesocycles consist mainly of pure, micritic (micro- to cryptocrystalline) limestone, partly dolomitized in the Nurmekund Formation. In general, the pure, micritic limestone, except tempestite interlayers, is almost barren of benthic shelly fossils and skeletal detritus. Relatively thin intercalations of marlstone or mudstone may contain kerogenous material and fragments of "dendroids" (e.g. in the Järva-Jaani and Jõgeva beds of the Nurmekund Formation), or graptoloids (in the Ikla Member of the Saarde Formation). An average limestone/ marlstone ratio is about 5:1 in central Estonia and 2:1 in southern Estonia.

These micritic lower parts of the Raikküla mesocycles display a similar shallowing upwards trend of development, expressed by an increase in the limestone/marlstone ratio and frequency of discontinuity surfaces and tempestite interlayers in the Nurmekund Formation, and are therefore treated as submesocycles. A submesocycle begins with a comparatively thin (about $0.5 \mathrm{~m}$ ) transgressive basal layer of rather uniform, fossil-rich argillaceous limestone or calcareous marlstone in the Nurmekund Formation or with a thicker (about $5 \mathrm{~m}$ ) stratum of argillaceous marlstone in the Saarde Formation. In central Estonian sequences, the lower boundary of the argillaceous basal layer is abrupt but the upper contact is rather transitional. In southern Estonia, both contacts of the basal layer are transitional, but the basal marlstone layer is traditionally included in the lower-lying Kolka or Lemme members, or is regarded as a separate unit (Heinaste Member, Fig. 6). In the Järva-Jaani and Jõgeva beds of the Nurmekund Formation, the frequency of discontinuity surfaces and tempestite interlayers increases gradually upwards in the intervals of micritic limestone, which shows a shallowing-up trend of development. In the Ikla core, the same trend is expressed by a change of graptolite-rich shaly interlayers in the lower part of the Ikla Member with marlstone interlayers devoid of graptolites in its upper part.

The upper parts (upper submesocycles) of the Raikküla mesocycles are represented by nodular, biomicritic, partly dolomitized limestone in the Nurmekund Formation and by marlstones or nodular argillaceous limestones in the Saarde Formation. Limestone nodules and interlayers alternate with argillaceous marlstone. The average limestone/marlstone ratio is $1: 1$ or less. The nodular biomicritic limestones of the Nurmekund Formation contain fine or unsorted skeletal detritus and rather rich benthic shelly fauna including corals and stromatoporoids. The deeper-water argillaceous limestones and marlstones of the Saarde Formation (Kolka and Lemme members) are almost devoid of bioclasts but contain scattered valves of brachiopods and some other shelly fossils. The argillaceous-bioclastic upper parts of the mesocycles show a somewhat similar shallowing-up trend of 
development as do the micritic lower parts. They, too, have commonly a more argillaceous and homogeneous transgressive basal layer, as well as discontinuity surfaces and tempestite interlayers in the topmost part. Also the limestone/marlstone ratio increases upwards.

From above it follows that both the lower (micritic) and upper (argillaceousbioclastic) parts of the Raikküla mesocycles reveal an almost similar shallowing upward trend of development, expressed by general increase in the limestone/marlstone ratio and growing frequency of tempestite interlayers and discontinuity surfaces in the Nurmekund Formation. The similar sedimentation trends allow us to treat the lower and upper parts of the mesocycles as submesocycles.

The formation of the pure, micritic carbonates is not unique to the Raikküla Stage of Estonia. The first two authors of the paper (H. Nestor and R. Einasto) have observed a very similar thick, cyclic deposit of micritic limestones in the middle Llandovery sequence of the Moiero River, Siberian Platform (Miagkova et al. 1977, figs. 39, 40, 42, 44). H. Nestor has recognized similar micritic carbonate rocks, dated to the Aeronian, in the Hendricks Member of the Burnt Bluff Group in Northern Michigan and R. Einasto in Wisconsin. Jenkins (1978) has described three thin cycles of micritic limestones in the middle Llandovery of the Panuara area in central New South Wales. This shows that wide deposition of pure lime muds in low-latitude carbonate platform settings of different continents in the middle Llandovery should have a global background.

In the Baltic area, cyclic sedimentation of pure lime muds began already in the latest Ordovician, being characteristic of the differentiation stage of basin development which ranged from Rakvere to Raikküla ages (H. Nestor \& Einasto 1997). This stage includes nine episodes of the accumulation of pure lime muds: (1) Oandu-Rakvere (Rägavere Formation), (2) late Nabala (Saunja Formation), (3) early Pirgu (Moe and Svedasai formations), (4) middle Pirgu (Oostriku and Paroveja formations), (5) late Pirgu (Taučionys Formation), (6) early Juuru (Koigi, Ruja, and Sturi members), (7) early Raikküla (Järva-Jaani Beds, Slitere Member), (8) middle Raikküla (Jõgeva Beds, Ikla Member), and (9) late Raikküla (Mõhküla Beds, Staicele Member). These episodes of low input of terrigenous, clayey material alternate with episodes of higher input of terrigenous component when marls or argillaceous, bioclastic (skeletal) lime muds were deposited.

\section{DISCUSSION}

Alternation of pure micritic carbonates, very poor in benthic fauna, with marlstones and bioclastic limestones, rich in shelly fauna, suggests that the mediumscale mesocyclicity in the uppermost Ordovician and lowermost Silurian of Estonia was not directly controlled by water depth and facies oscillation due do sea-level variations, but was probably conditioned by a cyclic change of certain 
bio-geochemical conditions. (This does not concern submesocycles, probably conditioned by sea-level variations!) Jeppsson $(1990,1998)$ explained changes in carbonate production in epeiric and marginal seas by abrupt turnovers in oceanic states (episodes) due to rearrangement of ocean water circulation. This is difficult to prove because of fragmentary preservation of true oceanic sediments in the geological record.

Therefore it seems more likely that cyclicity in carbonate production was caused by alternation of arid and humid climate states. Bickert et al. (1997) explained differences in carbonate production in the Silurian of Gotland by changes in terrigenous input and freshwater runoff. These were more intensive during humid periods and weaker during arid periods and, respectively, more argillaceous and pure calcareous sediments accumulated. The salinity of sea water changed as well, being lower in humid and higher in arid periods. This might have affected the distribution of the benthic life which was very poor and specific (dasycladacean algae, "dendroids") during the late Ordovician-early Silurian episodes of lime mud accumulation.

The source of the lime mud forming thick deposits of pure micritic limestones in the uppermost Ordovician and lowermost Silurian of East Baltic is mysterious. Recent calcareous deposits are prevailingly of biogenic origin. The upper Ordovician micritic limestones contain fragments of dasycladacean algae (Cyclocrinites, Vermiporella, Dasyporella, Rhabdoporella) (Põlma 1982), but in too low frequency for producing lime mud in large quantities. Therefore a biochemical or microbial origin of lime muds is more likely. Pratt (2001) suggested that calcification of benthic filamentous cyanobacteria, disintegrated during bioturbation and wave agitation, could have produced a significant amount of lime mud in the early Palaeozoic carbonate platform settings. It is conceivable that cyclic deposits of micritic limestones in the uppermost Ordovician and lowermost Silurian could have the same origin. It means that episodic aridizations could induce increase in salinity and changes in normal-marine benthic fauna with specific cyanobacterian assemblages capable of producing lime mud in large quantities.

Bickert et al. (1997) stated that carbon and oxygen isotope values were higher during the arid periods of high carbonate production. The same tendency has been observed in several East Baltic upper Ordovician and lower Silurian sections (Kaljo \& Martma 2000; Ainsaar et al. 2001). Cyclic deposition of pure lime muds in the Baltic basin is associated with some extensive sedimentation breaks. At least two of them, at the end of the Porkuni and Raikküla stages, are definitely of glacioeustatic origin (e.g. Kaljo et al. 1992; H. Nestor \& V. Nestor 2002). Several glaciations have been established in the latest Ordovician and earliest Silurian in South America (e.g. Caputo 1998). Thus we may conclude that the described cycles of lime mud accumulation were probably characteristic of the supposable late Ordovician-early Silurian icehouse period (e.g. Frakes et al. 1992) in some low-latitude marginal or epicontinental seas. 


\section{CONCLUSIONS}

Lower-middle Llandovery sections of three drill cores (Põltsamaa, Heimtali, and Ikla) were biostratigraphically correlated by means of chitinozoans and conodonts. Synchroneity of extensive strata of micritic limestones recurring three times in the sequence of the Raikküla Stage was proved. Pure, micritic limestones, almost barren of benthic shelly fossils, alternate with more argillaceous, nodular, biomicritic limestones (skeletal packstones and wackestones) in the Nurmekund Formation and with marlstones or argillaceous limestones in the Saarde Formation. Alternation of micritic calcareous deposits, very poor in benthic fauna, with argillaceous, biomicritic deposits, rich in shelly fauna, suggests that such cyclicity of mesocycle level was not directly controlled by changes in water depth, but more likely by cyclic change of certain biogeochemical conditions. Alternation of arid and humid climate states is supposed to have induced lime mud accumulation cycles. During humid periods terrigenous input and freshwater runoff from the adjacent continent produced more argillaceous sediments. During arid periods terrigenous input decreased, but salinity increased and pure lime muds, probably produced by benthic filamentous cyanobacteria, accumulated. Cyclic accumulation of lime muds in low-latitude shallow seas was characteristic of the supposable late Ordovician-early Silurian icehouse period.

\section{ACKNOWLEDGEMENTS}

This study was carried out in the Institute of Geology at Tallinn Technical University and was supported by the Estonian Science Foundation (grants Nos. 3749, 4070, and 5088). The help of K. Ronk with preparation of the figures is acknowledged.

\section{REFERENCES}

Aaloe, A., Kaljo, D., Klaamann, E., Nestor, H. \& Einasto, R. 1976. Stratigraphical classification of the Estonian Silurian. ENSV TA Toim. Keemia Geol., 25, 38-45 (in Russian).

Ainsaar, L., Meidla, T., Martma, T. \& Tinn, O. 2001. Upper Ordovician stable isotope correlation across the facies belts in the East Baltic. In WOGOGOB-2001 Abstracts (Harper, D. A. T. \& Stouge, S., eds.), pp. 5-6. Copenhagen.

Armstrong, H. A. 1990. Conodonts from the Upper Ordovician-Lower Silurian carbonate platform of North Greenland. Grønlands Geol. Unders., 159.

Bickert, T., Pätzold, J., Samtleben, C. \& Munnecke, A. 1997. Paleoenvironmental changes in the Silurian indicated by stable isotopes in brachiopod shells from Gotland, Sweden. Geochim. Cosmochim. Acta, 61, 2717-2730.

Bischoff, G. C. O. 1986. Early and middle Silurian conodonts from midwestern New South Wales. Cour. Forschungsinst. Senckenberg, 89.

Caputo, M. V. 1998. Ordovician-Silurian glaciations and global sea-level changes. In Silurian Cycles. Linkages of Dynamic Stratigraphy with Atmospheric, Oceanic, and Tectonic Changes (Landing, E. \& Johnson, M. E., eds.). New York State Mus. Bull., 491, 15-25. 
Dufka, P. 1992. Lower Silurian chitinozoans of the Prague Basin (Barrandian Czechoslovakia) preliminary results. Rev. Micropaleont., 35, 117-126.

Frakes, L. A., Francis, J. \& Syktus, J. I. 1992. Climate Modes of the Phanerozoic: the History of the Earth's Climate Over the Past 600 Million Years. Cambridge University Press.

Jenkins, C. J. 1978. Llandovery and Wenlock stratigraphy of the Panuara area, central New South Wales. Limestone Soc. N.S.W. Proc., 102, 109-130.

Jeppsson, L. 1990. An oceanic model for lithological and faunal changes tested on the Silurian record. J. Geol. Soc. London, 147, 663-674.

Jeppsson, L. 1998. Silurian oceanic events: a summary of general characteristics. In Silurian Cycles. Linkages of Dynamic Stratigraphy with Atmospheric, Oceanic, and Tectonic Changes (Landing, E. \& Johnson, M. E., eds.). New York State Mus. Bull., 491, 239-257.

Kaljo, D. 1970. Graptolites. In The Silurian of Estonia (Kaljo, D., ed.), pp. 179-185. Valgus, Tallinn (in Russian).

Kaljo, D. 1977. Structural and facial subdivisions of the East Baltic Silurian basin. In Facies and Fauna of the Baltic Silurian (Kaljo, D., ed.), pp. 6-13. Academy of Sciences of the Estonian SSR, Tallinn (in Russian).

Kaljo, D. \& Martma, T. 2000. Carbon isotopic composition of Llandovery rocks (East Baltic Silurian) with environmental interpretation. Proc. Estonian Acad. Sci. Geol., 49, 267-283.

Kaljo, D. \& Vingisaar, P. 1969. On the sequence of the Raikküla Stage in southernmost Estonia. ENSV TA Toim. Keemia Geol., 18, 270-277 (in Russian).

Kaljo, D., Paškevičius, J. \& Ulst, R. 1984. Graptolite zones of the East Baltic Silurian. In Stratigrafiya drevnepaleozojskikh otlozhenii Pribaltiki (Männil, R. \& Mens, K., eds.), pp. 94-118. Akademiya nauk ESSR, Tallinn (in Russian).

Kaljo, D., Nestor, H., Põlma, L. \& Einasto, R. 1992. Late Ordovician glaciation and its reflection on sedimentation in Paleobaltic basin. In Major Biological Events in Earth History (Kaljo, D., Modzalevskaya, T. \& Bogdanova, T., eds.), pp. 68-78. Tallinn (in Russian).

Loydell, D. K., Männik, P. \& Nestor, V. Integrated biostratigraphy of the lower Silurian of the Aizpute-41 core, Latvia. Geol. Mag. (in press).

Männik, P. 1992. Upper Ordovician and lower Silurian conodonts in Estonia. Unpublished Ph.D. thesis, University of Tartu, Estonia (in Russian).

Männik, P. 1994. Conodonts from the Pusku Quarry, lower Llandovery, Estonia. Proc. Estonian Acad. Sci. Geol., 43, 183-191.

Männik, P. 2001. Evolution of Early Silurian conodont faunas, and high-resolution stratigraphy. In Evolution of Life on the Earth: Proceedings of the II International Symposium "Evolution of Life on the Earth" November 12-15, 2001, Tomsk (Podobina, V. M., Rodygin, S. A., Savina, N. I. \& Tatianin, G. M., eds.), pp. 202-205. NTL, Tomsk.

Miagkova, E. I., Nestor, H. E. \& Einasto, R. E. 1977. Ordovician and Silurian Sequence of the Moiero River. Nauka Siberian Branch, Novosibirsk (in Russian).

Nestor, H. 1993. Catalogue of Silurian Stratigraphic Units and Stratotypes in Estonia and Latvia. Tallinn.

Nestor, H. 1997. Silurian. In Geology and Mineral Resources of Estonia (Raukas, A. \& Teedumäe, A., eds.), pp. 89-106. Estonian Academy Publishers, Tallinn.

Nestor, H. \& Einasto, R. 1977. Facies-sedimentary model of the Silurian Paleobaltic pericontinental basin. In Facies and Fauna of the Baltic Silurian (Kaljo, D., ed.), pp. 89-121. Academy of Sciences of the Estonian SSR, Tallinn (in Russian).

Nestor, H. \& Einasto, R. 1997. Ordovician and Silurian carbonate sedimentation basin. In Geology and Mineral Resources of Estonia (Raukas, A. \& Teedumäe, A., eds.), pp. 89-106. Estonian Academy Publishers, Tallinn.

Nestor, H. \& Kala, E. 1968. A stratigraphic revision of the lowermost Silurian in the northern East Baltic area. In Stratigraphy of the Baltic Lower Paleozoic and Its Correlation with Other Areas (Grigelis, A., ed.), pp. 188-214. Mintis, Vilnius (in Russian). 
Nestor, H. \& Nestor, V. 2002. Upper Llandovery to middle Wenlock (Silurian) lithostratigraphy and chitinozoan biostratigraphy in southwestern Estonia and northernmost Latvia. Proc. Estonian Acad. Sci. Geol., 51, 67-87.

Nestor, H., Einasto, R., Nestor, V., Märss, T. \& Viira, V. 2001. Type section, cyclicity, and correlation of the Riksu Formation (middle Wenlock, Estonia). Proc. Estonian Acad. Sci. Geol., 50, 149-173.

Nestor, V. 1994. Early Silurian Chitinozoans of Estonia and North Latvia. Academia, 4. Estonian Academy Publishers, Tallinn.

Nestor, V. 1998. Chitinozoan biofacies of late early Llandovery (Coronograptus cyphus) age. Proc. Estonian Acad. Sci. Geol., 47, 219-228.

Põlma, L. 1982. Comparative Lithology of the Ordovician Carbonate Rocks in Northern and Middle East Baltic. Valgus, Tallinn.

Pratt, B. R. 2001. Calcification of cyanobacterial filaments: Girvanella and the origin of lower Paleozoic lime mud. Geology, 29, 763-766.

Rubel, M. 1977. Evolution of the genus Stricklandia (Pentamerida, brach.) in the Llandovery of Estonia. In Facies and Fauna of the Baltic Silurian (Kaljo, D., ed.), pp. 193-212. Academy of Sciences of the Estonian SSR, Tallinn (in Russian).

Verniers, J., Nestor, V., Paris, F., Dufka, P., Sutherland, S. \& Van Grootel, G. 1995. A global Chitinozoa biozonation for the Silurian. Geol. Mag., 132, 651-666.

\title{
Kesk- ja Lõuna-Eesti Alam- ja Kesk-Llandovery läbilõigete korrelatsioon ja lubimudade settetsüklid
}

\author{
Heldur Nestor, Rein Einasto, Peep Männik ja Viiu Nestor
}

Kirjeldatakse ja korreleeritakse Põltsamaa, Heimtali ja Ikla puuraugu Juuru ja Raikküla lademe läbilõikeid ning analüüsitakse konodontide ja kitinosoade levikut. Tsükliliselt korduvad mudaliste (mikriitsete) lubjakivide lasundid Raikküla lademes on üheaegsete piiridega ja nad vahelduvad mudalis-detriitsete lubjakivide või merglitega. Mikriitsed lubjakivid on tekkinud ariidse kliima tingimustes, mudalis-detriitsed lubjakivid ja merglid aga humiidsetel perioodidel. Seda tüüpi settetsüklid olid iseloomulikud nn külmhoone ehk jäätumise perioodidele. 